\title{
Dynamics of agricultural use differentially affect soil properties and crop response in East African wetlands
}

Article in Wetlands Ecology and Management · December 2013

DOI: $10.1007 /$ s11273-013-9315-5

\section{CITATIONS}

6

3 authors:

\section{Hellen Wangechi Kamiri}

Karatina University Kenya

7 PUBLICATIONS 55 CITATIONS

SEE PROFILE

\section{Becker}

University of Bonn

93 PUBLICATIONS 1,692 CITATIONS

SEE PROFILE
READS

115
Christine Kreye

International Institute of Tropical Agriculture 14 PUBLICATIONS 364 CITATIONS

SEE PROFILE

Some of the authors of this publication are also working on these related projects: 
Dynamics of agricultural use differentially affect soil properties and crop response in East African wetlands

\section{Hellen Kamiri, Christine Kreye \& Mathias Becker}

Wetlands Ecology and Management

ISSN 0923-4861

Wetlands Ecol Manage

DOI 10.1007/s11273-013-9315-5
Volume 21 Issue 4

August 2013

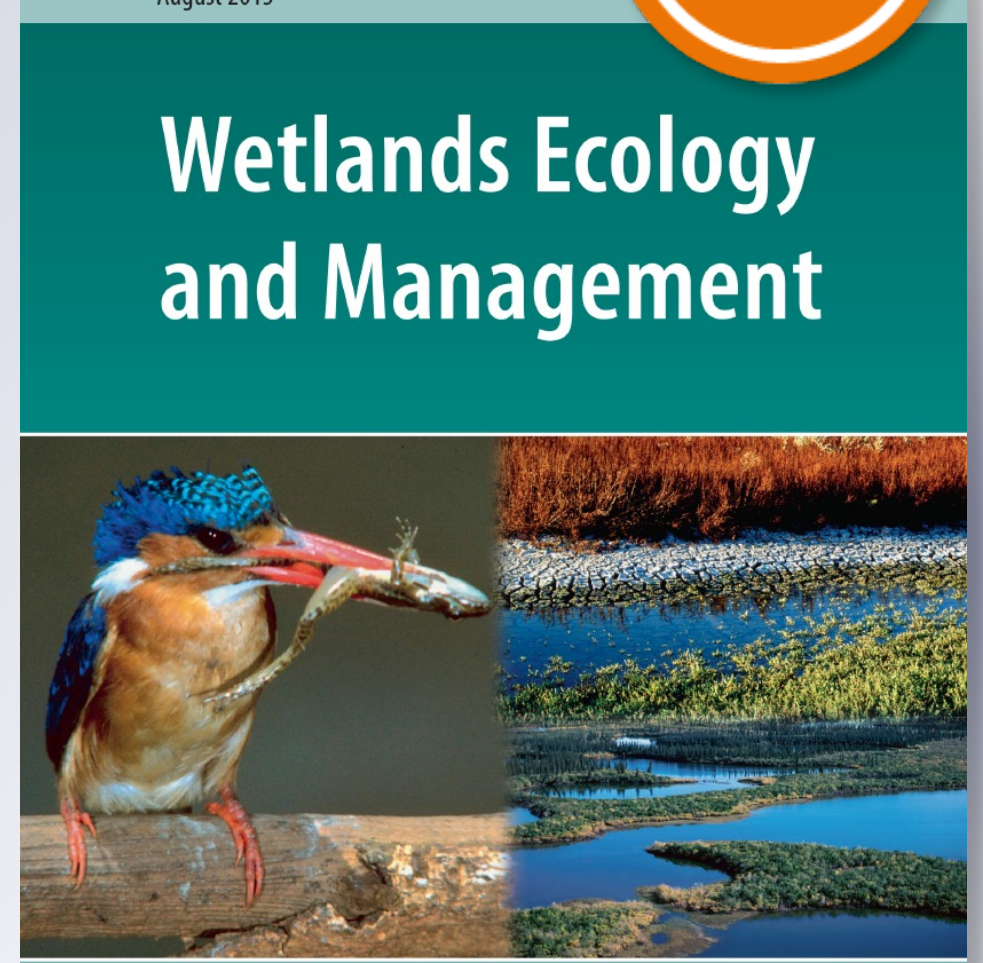

Springer

囪 Springer 
Your article is protected by copyright and all rights are held exclusively by Springer Science +Business Media Dordrecht. This e-offprint is for personal use only and shall not be selfarchived in electronic repositories. If you wish to self-archive your article, please use the accepted manuscript version for posting on your own website. You may further deposit the accepted manuscript version in any repository, provided it is only made publicly available 12 months after official publication or later and provided acknowledgement is given to the original source of publication and a link is inserted to the published article on Springer's website. The link must be accompanied by the following text: "The final publication is available at link.springer.com". 


\title{
Dynamics of agricultural use differentially affect soil properties and crop response in East African wetlands
}

\author{
Hellen Kamiri · Christine Kreye • Mathias Becker
}

Received: 14 December 2012 / Accepted: 20 July 2013

(C) Springer Science+Business Media Dordrecht 2013

\begin{abstract}
Agricultural land use changes differentially affect soil fertility and crop production potential of wetlands. We studied East African wetlands with contrasting hydro-geological characteristics (highand lowland floodplains and valley swamps). Land uses ranged from no use and grazing over crop production in flooded and drained fields to abandonment. We classified the dynamics of wetlands' conversion into agricultural sites and assessed selected soil fertility attributes associated with land use changes, and their effect on the crop production potential in aerobic and anaerobic soils. A conversion of pristine wetlands, differing in soil physical and chemical attributes, into sites of production tended to negatively affect soil total $\mathrm{C}$ and $\mathrm{N}$. Effects were stronger with soil drainage and in the coarse-textured soils of the lowland floodplain and the mid-hill valleys. Mineral $\mathrm{P}$ application in drained valleys significantly increased available soil P. Crop response followed these patterns with usually higher biomass accumulation and nutrient uptake in flooded than
\end{abstract}

\section{H. Kamiri}

School of Agriculture and Biotechnology, Karatina

University College, P.O. 1957-10101, Karatina, Kenya

C. Kreye · M. Becker $(\square)$

Department of Plant Nutrition, Institute of Crop Science and Resource Conservation (INRES), University of Bonn, Karlrobert-Kreiten-Str. 13, 53115 Bonn,

Germany

e-mail: mathias.becker@uni-bonn.de aerobic soils. Wetlands of fine soil texture in the highlands appeared more resilient than coarse-textured soils, particularly when drained. Enhanced crop performance in flooded soils indicates the possibility for partial recovery of the production potential and the rehabilitation of some wetlands.

Keywords Carbon - Drainage - Floodplain · Inland valley $\cdot$ Nitrogen $\cdot$ Oryza glaberrima

\section{Introduction}

Wetland ecosystems occupy relatively large areas in Sub-Saharan Africa (6\% of the land surfaceStevenson and Frazier 1999). They are considered to have a higher production potential and are often perceived to be more resilient than upland ecosystems (Millennium Ecosystem Assessment-MEA 2005) to anthropogenic interventions such as tillage and drainage measures that affect general soil fertility but also composition of non-crop species. Resilience has been defined as the extent of disturbance that a system can absorb without losing its integrity (Anderies et al. 2004). In the present context, however, resilience rather refers to being "better endowed in maintaining soil fertility" (Sahrawat 2004). In Kenya, for instance, a profound transition is underway as smallholder farmers move from subsistence cereal based upland farming to mixed enterprise and increasingly marketoriented production systems in wetlands (Sakane et al. 
2011). The urban centers with expanding marketing opportunities are viewed as the major stimulus for a shift towards the production of high-value commodities in wetlands (Jeroen et al. 2004). Today, wetlands in East Africa provide 10-40 \% of the annual food needs of the rural population (Schuyt 2005), and this share can rise to $100 \%$ during periods of food shortage (Rebelo et al. 2010). The dependence on wetlands for food security is particularly high in the densely populated highlands of East Africa (Millennium Ecosystem Assessment-MEA 2005).

A shift from upland to lowland production requires wetland clearing and drainage, and is associated with cropping intensification with or without the application of external inputs. Such trends are particularly prominent in the small wetlands, which can be cleared and cultivated without major investments in infrastructure and adoption of technological innovations, and is resulting eventually in a complete conversion of such wetland systems (Wood and van Halsema 2008; Mwita et al. 2012).

Despite their current and projected future importance, the claiming of wetlands for production often occurs without considering possible losses in the provision of ecosystem services (Daily et al. 2009) or of their carrying capacity (Silvius et al. 2000). While wetlands are expected to increasingly absorb the growing pressure on land for food production (Verhoeven and Setter 2010), this potential may be considerably reduced with inappropriate intensified land use, particularly where soils are inherently fragile or when agricultural production entails large-scale drainage measures (van der Heyden and New 2003). Thus, indiscriminate conversion of wetlands not only destroys hotspots of biodiversity, it has in some instances reportedly also lead to depletion of soil resources and a decline in production potential (Regmi et al. 2002). Dixon and Wood (2003) could show that the conversion of a pristine wetland into farmland in Ethiopia led to reduced water availability and declining crop yields. Particularly the decline in soil carbon and nitrogen that is associated with wetland drainage is likely to affect productivity as reported earlier from diverse tropical upland (Becker and Johnson 2001; Hartemink 2006; Balasubramanian et al. 2007) and paddy rice systems (Ladha et al. 2003; Roth et al. 2011). The soil aeration status influences not only the biogeochemistry of soils (Kirk 2004), it also affects C and $\mathrm{N}$ stocks and availability and determines plant growth and production potential (Mitsch and Gosselink 2007). While organic $C$ can accumulate under anaerobic conditions (Bernal and Mitsch 2008), the aeration of wetland soils promotes mineralization and the subsequent decline in soil $\mathrm{C}$ and $\mathrm{N}$ (Brady and Weil 2008). The extent of such $\mathrm{C}$ and $\mathrm{N}$ losses associated with changes in soil aeration status differ with climatic conditions and soil texture (Becker et al. 1994). While several studies have reported soil property changes with wetland use change and intensification in East Africa (Ndakidemi and Semoka 2006; Thenya 2001), no data are available on differential effects of the prevailing major land uses and a comparison across different wetland types. In representative wetlands of Kenya and Tanzania, we investigated the dynamics of wetland conversion into sites for agricultural production, and the impact of the major land uses along gradients of intensification on soil $\mathrm{C}, \mathrm{N}$, and $\mathrm{P}$ contents. The effects of land userelated soil parameter changes and of the soil aeration status (aerobic vs. flooded) were additionally assessed in a greenhouse study.

\section{Materials and methods}

\section{Wetland selection}

Based on a comprehensive characterization of agriculturally used wetlands in East Africa (Sakane et al. 2011) we selected four sites representing the major hydro-geomorphological characteristics of small wetlands in the region. These comprised inland valley swamps either on volcanic material in the humid zone (Mt Kenya, Kenya) or on metamorphic rocks in the sub-humid mid-hills (Usambara Mountains, Tanzania) and floodplains, either in the semi-arid highlands (Laikipia, Kenya), or the sub-humid lowlands (Pangani, Tanzania). The geographical location of the wetland sites is presented in Fig. 1. Major biophysical attributes of the environment, wetland use characteristics, and selected soil parameters are shown in Table 1.

Each wetland site presented a range of land uses including undisturbed segments, extensively used undrained areas, intensively cropped drained field plots, and abandoned or grazed fallow areas. The type of land use has previously been classified and quantitatively assessed by remote sensing approaches (Mwita 
Fig. 1 Location and topography of the study sites in East Africa (Kenya and Tanzania; adopted from Mwita et al. 2012)

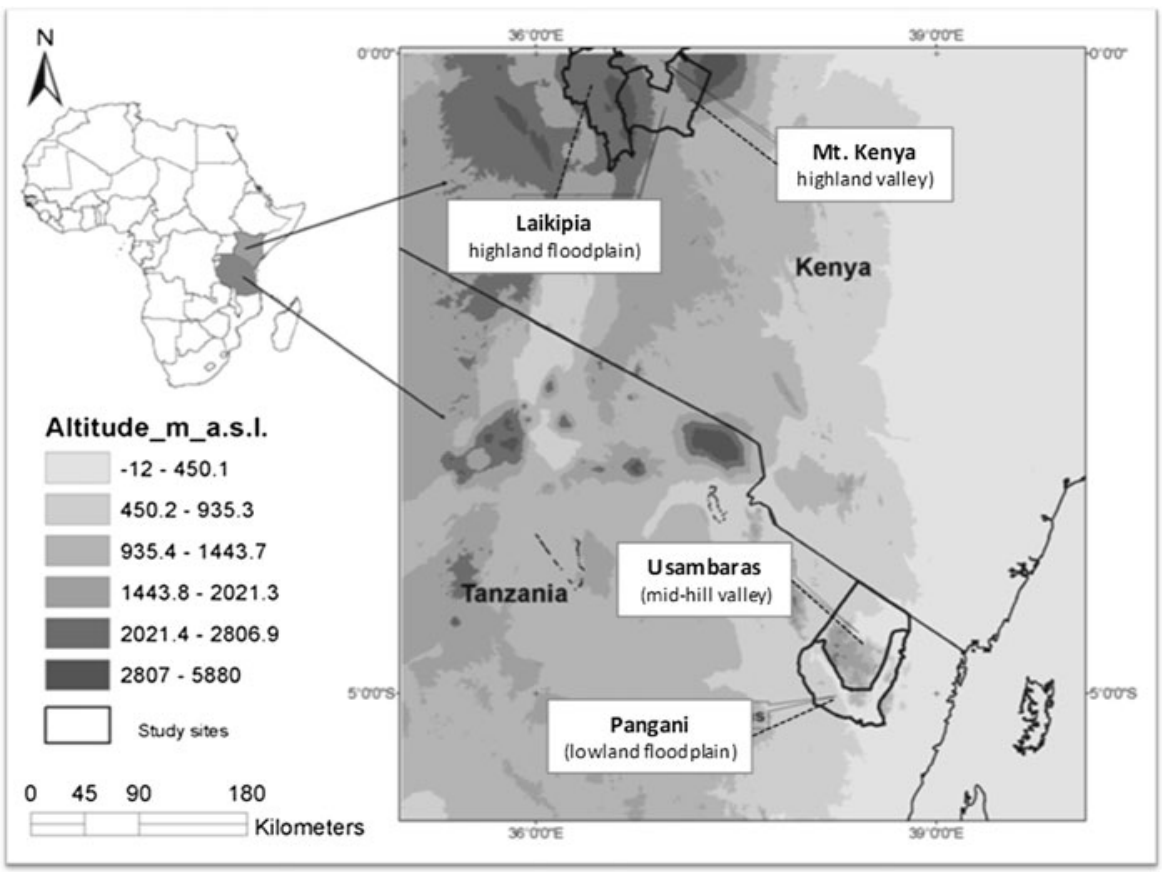

et al. 2012). A summary of the share of major land use types within the four wetland sites is presented in Table 2. Within each wetland and each major land use type, 2-7 farmers and other wetland users were interviewed regarding the sequence in land use changes, production attributes and perceived constraints associated with abandoning cultivation ( $n=89$ users). Details to farmer attributes, drivers of land use, and a typology of wetland users have been presented by (Sakane et al. 2011, 2012). The information on the sequence of wetland conversion and perceived constraints was compiled in a conceptual model of the evolutionary stages in wetland use. Within each of the major wetland use types (floodplain vs. inland valley, flooded vs. aerobic soil, unused vs. cropped vs. abandoned site), three field areas were selected for vegetation assessment and soil sampling $(n=18)$. Within the four wetland types, these land uses comprised:

1. Unused areas-These sections of the wetlands were largely undisturbed by human activity, apart from the occasional collection of thatching material and some fishing and gathering activities. They showed the hydrological regime typical for the respective wetland types in a pristine stage (seasonal or permanent flooding) and served as reference samples. There was no nutrient application in these areas.

2. Grazed areas-These subsections were used as grazing grounds for ruminants, but differed strongly in grazing regime and soil aeration status between wetland types. While in the highland floodplain, the moist fringe areas of the Papyrus swamp were used for year-round extensive grazing, the otherwise undisturbed and seasonally flooded central part of the lowland floodplain was used during the dry season as grazing ground. In the two valley sites, grazing was restricted to fallow land and abandoned plots that had been formerly drained and used for food crop production for several years. There was no nutrient application in these areas.

3. Anaerobic cropping-For the purpose of this paper, rice and taro are used to form one class of crops that can withstand more aerobic soil conditions than maize and vegetables, although, especially taro, is cropped under almost saturated as well as under quite aerobic conditions. Thus, these areas were characterized by either seasonal flooding in the lowland floodplain used for wet season cultivation of lowland rice, or by yearround conditions, that ranged from largely water 
Table 1 Site characteristics and selected soil attributes of the four study sites in East Africa

\begin{tabular}{|c|c|c|c|c|}
\hline \multirow[t]{2}{*}{ Parameter $^{\mathrm{a}}$} & \multicolumn{4}{|l|}{ Site } \\
\hline & Lowland floodplain & Highland floodplain & $\begin{array}{l}\text { Highland valley } \\
\text { swamp }\end{array}$ & Mid-hill valley swamp \\
\hline Site name & Pangani & Laikipia & Mt. Kenya & Lukozi \\
\hline Longitude & $\begin{array}{c}38^{\circ} 19^{\prime} 32^{\prime \prime} \mathrm{E} \text { to } \\
38^{\circ} 21^{\prime} 28^{\prime \prime} \mathrm{E}\end{array}$ & $\begin{array}{c}36^{\circ} 34^{\prime} 59^{\prime \prime} \mathrm{E} \text { to } \\
36^{\circ} 32^{\prime} 26^{\prime \prime} \mathrm{E}\end{array}$ & $\begin{array}{r}37^{\circ} 6^{\prime} 7^{\prime \prime} \mathrm{E} \text { to } \\
37^{\circ} 5^{\prime} 57^{\prime \prime} \mathrm{E}\end{array}$ & $\begin{array}{c}38^{\circ} 13^{\prime} 54^{\prime \prime} \mathrm{E} \text { to } \\
38^{\circ} 16^{\prime} 22^{\prime \prime} \mathrm{E}\end{array}$ \\
\hline Latitude & $5^{\circ} 4^{\prime} 29^{\prime \prime} \mathrm{S}$ to $5^{\circ} 6^{\prime} 57^{\prime \prime} \mathrm{S}$ & $\begin{array}{c}0^{\circ} 19^{\prime} 16^{\prime \prime} \mathrm{N} \text { to } \\
0^{\circ} 15^{\prime} 17^{\prime \prime} \mathrm{N}\end{array}$ & $\begin{array}{c}0^{\circ} 27^{\prime} 58^{\prime \prime} \mathrm{S} \text { to } \\
0^{\circ} 28^{\prime} 51^{\prime \prime} \mathrm{S}\end{array}$ & $4^{\circ} 38^{\prime} 18^{\prime \prime} \mathrm{S}$ to $4^{\circ} 40^{\prime} 12^{\prime \prime} \mathrm{S}$ \\
\hline Altitude (masl) & $300-400$ & $1,900-2,300$ & $1,200-1,800$ & $800-1,000$ \\
\hline Climate & Sub-humid & Semi-arid & Humid & Humid \\
\hline Rainfall (mm) & $500-800$ & $400-1,000$ & $950-1,500$ & $1,200-1,500$ \\
\hline Soil class & Fluvisol & Fluvisol & Gleysol & Gleysol \\
\hline $\begin{array}{l}\text { Aeration status (soil } \\
\text { flooding) }\end{array}$ & Seasonal & Permanent & Permanent & Seasonal \\
\hline Soil texture ${ }^{\mathrm{b}}$ & $\mathrm{sC}$ & $1 \mathrm{C}$ & $\mathrm{C}$ & $\mathrm{sCL}$ \\
\hline Sand $(\%)$ & 47 & 17 & 13 & 56 \\
\hline Silt $(\%)$ & 20 & 21 & 29 & 15 \\
\hline Clay $(\%)$ & 33 & 62 & 65 & 29 \\
\hline $\mathrm{pH}\left(\mathrm{H}_{2} \mathrm{O}\right)$ & 6.3 & 5.8 & 5.0 & 5.7 \\
\hline $\mathrm{EC}\left(\mathrm{dS} \mathrm{m} \mathrm{m}^{-1}\right)$ & 2.8 & 0.6 & 0.4 & 1.2 \\
\hline Ap horizon depth (m) & 0.29 & 0.21 & 0.14 & 0.16 \\
\hline Bulk density $\left(\mathrm{g} \mathrm{cm}^{-3}\right)$ & 1.34 & 1.01 & 1.03 & 1.26 \\
\hline $\mathrm{C}_{\text {org }}$ content $\left(\mathrm{g} \mathrm{kg}^{-1}\right)$ & 30.5 & 39.6 & 34.1 & 33.2 \\
\hline $\mathrm{C}$ stock $\left(\mathrm{Mg} \mathrm{ha}^{-1}\right)$ & 115 & 81 & 49 & 67 \\
\hline $\mathrm{Nt}_{\mathrm{ot}}$ content $\left(\mathrm{g} \mathrm{kg}^{-1}\right)$ & 3.0 & 3.2 & 3.2 & 3.0 \\
\hline $\mathrm{N}$ stock $\left(\mathrm{Mg} \mathrm{ha}^{-1}\right)$ & 10.1 & 6.1 & 4.6 & 6.0 \\
\hline $\mathrm{P}_{\text {avail }}$ content $\left(\mathrm{mg} \mathrm{kg}^{-1}\right)^{\mathrm{c}}$ & 7.2 & 15.9 & 18.7 & 15.7 \\
\hline $\mathrm{P}$ stock $\left(\mathrm{Mg} \mathrm{ha}^{-1}\right)$ & 28.8 & 32.2 & 27.8 & 31.7 \\
\hline $\mathrm{K}_{\text {exch }}$ content $\left(\mathrm{cmol} \mathrm{kg}^{-1}\right)^{\mathrm{c}}$ & 0.4 & 1.2 & 0.6 & 0.7 \\
\hline $\mathrm{K}$ stock $\left(\mathrm{Mg} \mathrm{ha}^{-1}\right)$ & 4.0 & 10.1 & 3.5 & 5.6 \\
\hline
\end{tabular}

${ }^{a}$ Values are means of three individual samples

b $C$ clay, $s C$ sandy clay, $l C$ silty clay, $s C L$ sandy clay loam

c Soil $\mathrm{P}$ and $\mathrm{K}$ by modified Olsen extraction

saturated to drained conditions on raised beds, in highland valleys used for the cultivation of taro (Colocasia esculenta). In the highland floodplain and the mid-hill valleys, cultivation under anaerobic soil conditions was spatially restricted or occurred only for one season during clearing and wetland drainage and was consequently not considered as a treatment in this study. There was modest application of organic inputs.

4. Aerobic cropping - The cultivation of upland field crops differed in intensity and seasonality between wetland types. In all but the lowland floodplain, aerobic cropping entailed complete drainage of the soil. A dense network of artificial drainage channels around individual plots and a deep central drain allowed for year-round cultivation of maize or vegetables. In the lowland floodplain, maize cultivation was also associated with some rudimentary drainage measures (shallow ditches draining excess water towards the center of the floodplain) but was mainly restricted to the dry season. Nutrient application in these areas ranged from $10-100 \mathrm{~kg} \mathrm{~N}^{-1}$ to $10-15 \mathrm{~kg} \mathrm{P}^{-1}$.

5. Abandoned areas-These "degraded" sites in all four wetland types were formerly drained field plots with remnants of drainage channel structures 
Table 2 Share of land uses relative to total wetland area at the four study sites in East Africa in 2011 (based on Mwita et al. 2012)

\begin{tabular}{|c|c|c|c|c|}
\hline Land use type ${ }^{\mathrm{a}}$ & Lowland floodplain & Highland floodplain & Highland inland valley & Mid-hill inland valley \\
\hline \multicolumn{5}{|l|}{$\%$ of total land use } \\
\hline Unused areas & $17 *$ & $24 *$ & $6^{*}$ & $7 *$ \\
\hline Seasonal pasture & 6 & $15^{*}$ & $9 *$ & 0 \\
\hline Anaerobic cropping & $38 *$ & 0 & $44^{*}$ & 1 \\
\hline Aerobic cropping & $11 *$ & $43 *$ & $38 *$ & $72 *$ \\
\hline Grazed fallow & $19 *$ & 8 & 0 & $11^{*}$ \\
\hline Abandoned areas & $9 *$ & $10^{*}$ & $3 *$ & $9 *$ \\
\hline
\end{tabular}

* Land uses marked with an asterisk were selected for soil parameter analysis and for the crop response trial

${ }^{a}$ Unused areas: uncultivated areas with natural wetland vegetation and some extensive non-crop uses; seasonal pasture: area extensively grazed during the dry season without soil drainage; anaerobic cropping: fields grown to flood-tolerant crops such as wet season rice or taro; aerobic cropping: drained and cultivated all year-round with upland crops; grazed fallow: formerly drained and cropped areas left to fallow and dry season grazing; abandoned areas: formerly drained crop fields that were abandoned for pest infestation and fertility decline

still visible. They had been cultivated with upland crops for several years before being abandoned. In some environments, the abandoned plot areas were extensively grazed. While most of the degraded (abandoned or grazed) plots had been taken out of crop production 1-2 years ago, the cultivated areas included in the study had been under the current use type continuously for at least 5 years. The fallow period of 1-2 years was not sufficient for appreciable recovery of soil fertility. There was no nutrient application in these areas.

\section{Soil sampling design}

A spatial analogue design was used to sample the soils. The design entailed comparing properties of soil samples taken from the wetland in three replications. Individual sampling sites and replications were located at maximum distances of $100 \mathrm{~m}$ from each other to minimize possible effects of geological, topographic or climatic variations. Differences in soil properties were thus assumed to be related only to differences in land use. As wetland uses represent typically a time sequence of land use change (unused $\rightarrow$ cleared or grazed $\rightarrow$ lowland cropping $\rightarrow$ drainage $\rightarrow$ aerobic cropping $\rightarrow$ abandoning of degraded land), this approach substituted space for time with unused areas representing the original and abandoned areas the climax stage of systems evolution. A similar approach has been used in upland cropping studies in
Ethiopia by Bewket and Stroosnijder (2003). In each land use type and replication, an area of $10 \times 20 \mathrm{~m}$ was demarcated. Bulk density samples were taken from three locations at 5-10 cm depth using $100 \mathrm{ml}$ sample rings. The cores were excavated and weighed fresh and weighed again after oven-drying at $105{ }^{\circ} \mathrm{C}$. Top soil $(0-15 \mathrm{~cm})$ was sampled as a composite from nine individual points collected in a ' $\mathrm{W}$ ' shaped design, using a 5-cm diameter soil auger. Samples were air-dried and passed through a $2 \mathrm{~mm}$ stainless steel sieve before the analysis for total C and N (CNS elemental analyzer, EuroEA 3000, Milan, Italy), available Olsen P (Eppendorf ECOM 6122 spectrophotometer) and exchangeable $\mathrm{K}$ (Eppendorf Elex 6361 flame photometer) after soil extraction with $0.5 \mathrm{M} \mathrm{NaHCO}_{3}+0.01 \mathrm{M}$ EDTA.

Effect of soil aeration status on crop responses to land uses

A greenhouse experiment was conducted at the Institute of Crop Science and Resource Conservation, University of Bonn, Germany, to determine the effect of the soil aeration status on biomass accumulation and nutrient uptake by rice grown in potted soil from the different wetland types and land uses described above. Plastic pots of $11 \mathrm{~cm}$ height and $6.5 \mathrm{~cm}$ diameter were filled with $220 \mathrm{~g}$ of soil. Three pots each were either maintained aerobic by adjusting the soil moisture to $80 \%$ field capacity by daily weighing and watering with distilled water, or anaerobic by maintaining $1 \mathrm{~cm}$ 
of standing floodwater. The aerobic pots received water through $13 \mathrm{~cm}$ long perforated tubes of $2 \mathrm{~cm}$ diameter inserted in the center of each pot. In addition, a $1 \mathrm{~cm}$ layer of acid-washed gravel was added at the bottom of the pots to facilitate drainage. In the anaerobic soil treatment, closed bottom pots were used. The 117 pots (4 wetland types, 4-5 land uses, 2 soil aeration regimes and 3 replications) were arranged in a completely randomized design.

Rice (Oryza glaberrima Steud) variety CG 14 was obtained from the Africa Rice Centre in Cotonou, Benin. It is reportedly adapted to both upland and lowland conditions with similar performance attributes. Seeds were soaked over-night and pre-germinated in sand-filled seedling trays for 8 days and transplanted at two seedlings per pot. The plants were grown in a greenhouse with $12 \mathrm{~h}$ day length, day/night temperatures of $27 / 20^{\circ} \mathrm{C}$, and a light intensity of $650-900 \mu \mathrm{mol} \mathrm{m} \mathrm{m}^{-2} \mathrm{~s}^{-1}$ for 32 days. Forty day-old rice plants were harvested and aboveground biomass was oven-dried at $70{ }^{\circ} \mathrm{C}$ for $72 \mathrm{~h}$ for dry matter determination and chemical analysis after fine-grinding. The plant $\mathrm{N}$ content was determined by an automated CNS elemental analyzer (EuroEA 3000, manufacturer: Euro Vector SpA, Milan, Italy). Plant P was determined after digestion in nitric acid and measured colorimetrically after molybdenum blue staining (Eppendorf ECOM 6122 spectrophotometer). Plant K was measured by flame photometry after dryashing (Eppendorf Elex 6361).

\section{Data analysis}

Effects of land use type on soil variables were tested individually for each wetland type by analysis of variance, while data from the greenhouse experiment were subjected to a two factorial analysis of variance with the factors land use type and soil aeration status. Mean separation was done by Tukey test $(P<0.05)$ using Genstat Version 7, service pack 1.

\section{Results}

Land use transformation

The land uses in the four selected wetlands were characterized and described in chronological order of wetland conversion based on maps, field observations and interviews. The land use followed a time sequence of conversion steps that differed by wetland type and is conceptualized in Fig. 2. A gradual expansion of the area under cultivation was associated with tillage, drainage or irrigation measures and characterized by predominating crop types.

Stage 1 Largely undisturbed wetland areas represent the starting point of land conversion. They were covered by natural vegetation that was determined by climate, soil and the hydrological regime. At the beginning of this study (2009), their area share ranged from 6 to $24 \%$ of the total wetland area, with lowest values in the inland valleys and highest in the floodplains (Table 2). In permanently flooded wetlands (highland floodplain and the central parts of all wetlands), semi-aquatic plants such as Cyperus papyrus in oligotrophic and Typha domingensis in eutrophic environments dominated the natural vegetation (Alvarez et al. 2012). Wetlands or wetland segments with seasonal flooding regimes were dominated by other Cyperus spp. (mainly Cyperus laevigatus and/or C. latifolius) and by Pennisetum spp. Water was in all cases extracted from these wetlands for bathing, washing, and other domestic uses. The areas were generally used for hunting, fishing and gathering of medicinal plants thatching grass and feed for animals. Vegetation on the wetland fringes was occasionally cut as thatching material or bedding for animals.

Stage 2 First agricultural uses involved an extensive grazing of the wetland fringe vegetation (highland floodplain) or grazing during the dry season (lowland floodplain). To accelerate the reestablishment of palatable species, segments of the area were burned at the beginning of the dry season at both floodplain sites. In the case of the highland valley, vegetation was cut several times during the years to provide forage to cattle kept at homesteads. No such forage uses occurred in the mid-hill valleys where animals play a minor role. Consequently, the land area under such seasonal grazing varied from $0 \%$ in the mid-hill valleys to $15 \%$ in the lowland floodplain.

Stage 3 Crop uses differed with the soil aeration status of the wetland. In the absence of investments in drainage infrastructure, partially or seasonally flooded wetland sections were cropped with flood-tolerant species such as lowland rice (Oryza sativa L.) during the wet season in the lowland floodplain or taro (Colocasia esculenta) mainly during the dry season in the highland inland valley. The share of this anaerobic cropping ranged from 38 to $44 \%$ of the total wetland 


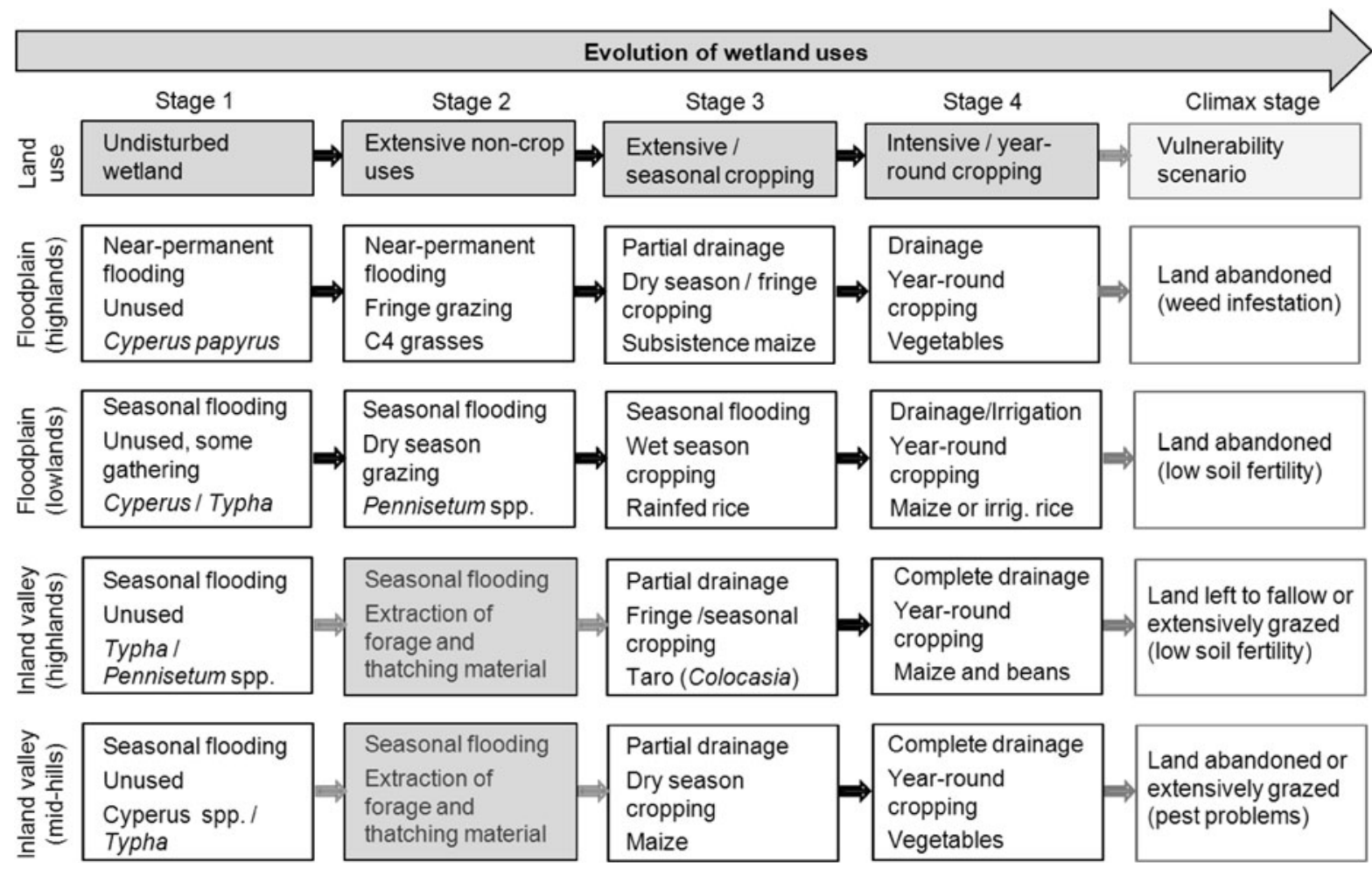

Fig. 2 Stages of wetland use transformation, including soil aeration status and main crops/vegetation. The climax stage may be sustained year-round crop production, but refers here to the

area with the exception of the mid-hill valleys where aerobic crop uses (Stage 4) occurred generally directly after the conversion from natural vegetation (Stage 1). Both crop types require tillage operations and consequently entail additional soil disturbances. In the case of rainfed lowland rice, this implied manual or machine tillage before dry-seeding or transplanting, while in the case of taro, large raised beds were constructed to prevent the submergence of the crop. In few cases, low rates of di-ammonium phosphate were applied to taro in the highland valley. Otherwise anaerobic cropping at all study sites occurred in the absence of either mineral or organic fertilizer applications.

Stage 4 The cultivation with typical upland crops (maize, maize-bean intercropping, or vegetables) requires drained, aerobic soil conditions. This implied a cultivation only of the well-drained fringe segments during the dry season (lowland floodplain), or the year-round production after investment in drainage infrastructure, entailing the construction of canals and field bunds around individual field plots and the vulnerability scenario. Shaded boxes refer to land use scenarios not evaluated in this study

excavation of a central drain (usually the natural water course). In all but the mid-hill valley (direct conversion of natural wetlands after large-scale drainage), drainage infrastructure was gradually established during extended periods of anaerobic land uses. The area share under aerobic crop production, the types of crops, and associated crop management practices differed by wetland sites. Low-input production of subsistence maize occupied $11 \%$ of the lowland floodplain. Subsistence maize-bean intercropping covered $38 \%$ of the highland valley area, maizevegetable rotations occupied $48 \%$ of the highland floodplain, and intense, continuous production of market-oriented vegetables (mainly cabbage and tomatoes) was the dominant land use in the mid-hill valley with an area share of $72 \%$. In the latter case, inorganic fertilizers were applied by most farmers at annual rates of $20-42 \mathrm{~kg} \mathrm{~N}$ and $10-15 \mathrm{~kg} \mathrm{P} \mathrm{ha}^{-1}$, while most other aerobic crop production systems received little to no external inputs. In all observed field plots, aerobic cropping had been practiced for $>5$ years. Some mid-hill valley parts and parts of the 
highland floodplain had been continuously cultivated for $>20$ years.

While such continuous cultivation of (high-value) aerobic crops is farmers' desired final stage of wetland development, wide-spread productivity declines after extended periods of cultivation have been reported by the interviewed farmers. Depending on the wetland type, these declines were reportedly associated predominantly with weed infestation (highland floodplain), soil fertility problems (lowland floodplain and both valley sites) and soil-born pests and diseases (mid-hill valleys), and led to abandoning of field crop plots to fallow or grazing land (Stages 5 and 6).

Stage 5 A large share of up to nearly $30 \%$ of some wetland areas has been (temporarily) abandoned by crop farmers. The vegetation in these areas was dominated by the grass Cynodon dactylon in all wetland environments. In the floodplains and also in some parts of the mid-hill valley, such fallow plots were either stocked with 1-3 heads of tethered cattle per plot (valley sites) or left as free grazing grounds for ruminants of nomadic pastoralists (highland floodplain) or of both pastoralists and sedentary farmers (lowland floodplain). Particularly in the lowland floodplain, most abandoned plots were used for dry season grazing (19\% of the area).

Stage 6 Truly abandoned areas were often difficult to separate from those still used for extensive grazing in the floodplain environments, as we relied on information by herders and guard boys, and the presence or absence of animal droppings in the plots. Thus, the estimates 9-10\% abandoned land area in the flood plain environments may still comprise some seasonally grazed fallow land. As in the grazed fallow plots, drainage canals required for aerobic crop production were still visible, though no longer maintained, in the abandoned field areas, indicating that both land use Stages 5 and 6 always follow the production of aerobic crops in drained fields (Stage 4).

\section{Soil parameter changes}

Topsoil samples from all major sequential land use stages were characterized for key fertility attributes. Trends in soil parameter changes are presented in the following paragraph. Soil $\mathrm{C}$ and $\mathrm{N}$ content varied between the wetland types and land uses and tended to decline over time with a conversion of natural wetlands into sites of aerobic crop production or in degraded and abandoned areas (Fig. 3). This decline was more pronounced in the warm lowland and midhill climate than in the cold highlands (where monthly minimum temperatures usually fall below $15^{\circ} \mathrm{C}$ ), and was more in floodplains than in the inland valley soils. While the $\mathrm{C}$ and $\mathrm{N}$ contents of all permanently and temporarily flooded soils (generally $>3 \% \mathrm{C},>0.25 \%$ $\mathrm{N})$ can be classified as high, those of drained and anaerobic soils $(1.5-3 \% \mathrm{C} ; 0.12-0.25 \% \mathrm{~N})$ are considered to be in the medium range. The $\mathrm{C}$ and $\mathrm{N}$ contents of soils from abandoned plots tended to be lowest but did not differ significantly from those under aerobic cropping.

Plant available $\mathrm{P}$ contents varied widely (4-20 mg kg${ }^{-1}$ ), but were generally higher at the highland than at the lowland or mid-hill sites, and were also generally lowest in the abandoned areas. However, highest $\mathrm{P}$ contents were observed for plots under aerobic crops in the mid-hill valley where farmers produced for the Dar-es-Salaam market and apply mineral $\mathrm{P}$ fertilizers at rates of $10-15 \mathrm{~kg} \mathrm{P} \mathrm{ha}^{-1}$ annually.

The soil extractable $\mathrm{K}$ ranged from very low to medium in the lowland floodplain $\left(0.1-0.3 \mathrm{cmol} \mathrm{K} \mathrm{kg}{ }^{-1}\right)$ to very high values $\left(>1.0 \mathrm{cmol} \mathrm{K} \mathrm{kg}^{-1}\right)$ in the highland floodplain, where the $\mathrm{K}$ stocks of about $10 \mathrm{Mg} \mathrm{ha}^{-1}$ were also highest. With $3.5 \mathrm{Mg} \mathrm{ha}^{-1}$, $\mathrm{K}$ stocks were lowest in the highland inland valley (Table 1). In no case, except for the mid-hill valley, did soil use significantly affect the $\mathrm{K}$ availability and data are consequently not presented in Fig. 3.

Effect of soil aeration status and land use on crop response

Rice biomass accumulated in potted soils varied from 110 to $>1,000 \mathrm{mg} \mathrm{plant}^{-1}$. It was generally higher in soils collected from the highland than from lowland sites and was in most cases significantly higher under flooded than under aerobic soil conditions (Fig. 4). While wetland use intensification, particularly when associated with soil drainage, significantly reduced biomass accumulation in all but the soils from the midhill site, re-flooding of the previously aerobic soil partially re-established the initial production potential in four out of eight cases. Such trends were also reflected in the nutrient uptake by rice plants. Thus, N, $\mathrm{P}$ and $\mathrm{K}$ accumulation was highest in soils from the highland sites, tended to be higher under anaerobic 


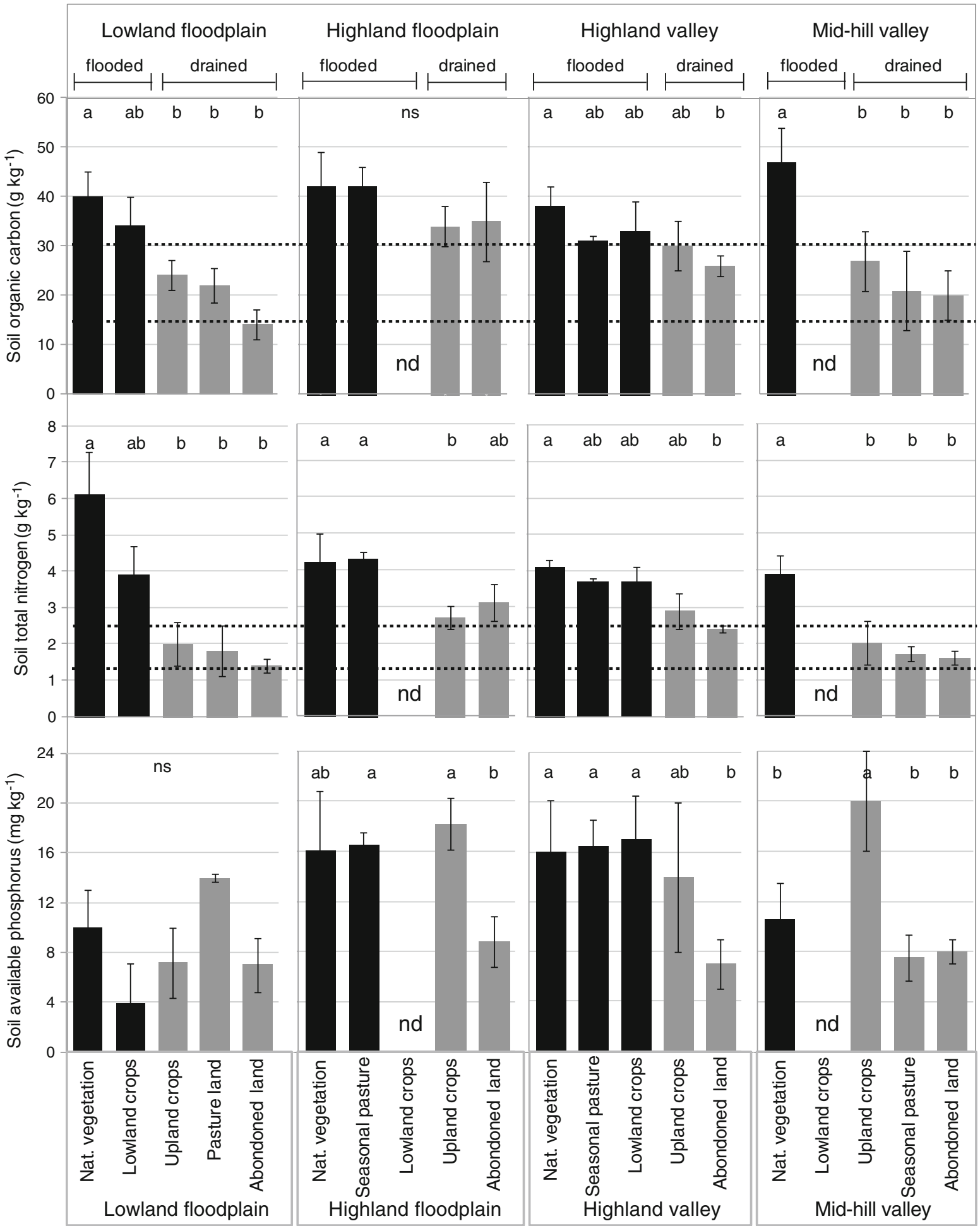

Fig. 3 Content of carbon, nitrogen and available phosphorus in top soils as affected by wetland type and land use. Bars represent standard error of the mean $(n=3)$. nd not determined-the specific land use type did not occur within the observation range in the field. Different letters indicate significant differences by one way analysis of variance and Tukey post hoc test at $P<0.05 ; n s$ indicates no significant difference 


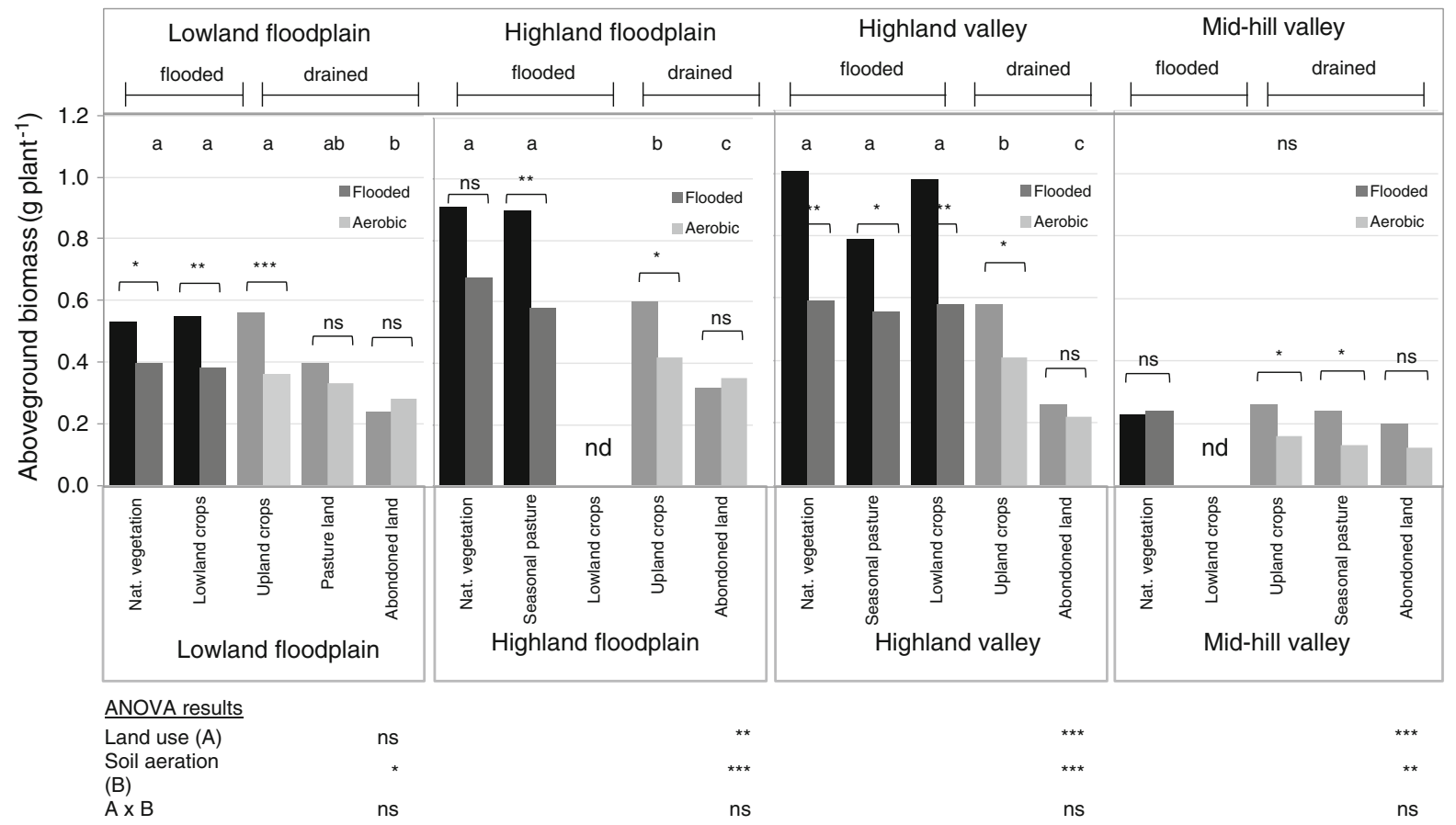

Fig. 4 Aboveground dry biomass of 40 day-old rice grown in a greenhouse under flooded and aerobic conditions in potted soil from the various wetland types and land uses. "Flooded" refers to of $1 \mathrm{~cm}$ of standing floodwater; "aerobic" refers to maintenance of $80 \%$ field capacity by daily weighing. $n d$ not determined-the specific land use type did not occur within the observation

than aerobic conditions, and declined with land use intensification (Table 3).

The $\mathrm{N}$ content in the biomass was on average $1.87 \%$ with a coefficient of variation $(\mathrm{CV})$ of $<34 \%$, irrespective of soil aeration status, wetland or land use type. The mean $\mathrm{P}$ content of $0.22 \%$ varied with a CV of $43 \%$ and plant $\mathrm{K}$ contents, averaging $1.19 \%$, varied with a $\mathrm{CV}$ of $44 \%$. The $\mathrm{N}$ uptake was highly correlated with biomass accumulation $\left(r^{2}=0.85\right)$, and a clear differentiation between flooded (anaerobic) and aerobic soil uses was apparent (Fig. 5). These trends were much less pronounced for $\mathrm{P}$ and $\mathrm{K}\left(\mathrm{r}^{2}\right.$ of 0.67 and 0.58 , respectively) and no differentiation by soil aeration status was apparent.

\section{Discussion}

Land use transformation

Distribution and changes of wetland uses are driven by biophysical characteristics of the wetland such as wetland. Different letters indicate significant differences between land uses (pooled for aerobic and anaerobic soil conditions) by one way analysis of variance and Tukey post hoc test at $P<0.05$; $n s$ indicates no significant difference. $*, * *, * * *$ indicate significant differences between soil aeration status in the greenhouse at $P \leq 0.05,0.01$, and 0.001 , respectively

water availability (Dixon and Wood 2003) and socioeconomic factors, including accessibility (Wood and van Halsema 2008) and market proximity (Oucho and Gould 1993). The most relevant drivers of land use changes of the wetlands in our study have been presented in more detail by Sakane et al. (2011). In addition to the above-mentioned factors, these drivers also include the land shortage and resource degradation phenomena in surrounding upland areas. In the four selected wetlands of this study, the growing demand for land and water resources for food production was the key driver of the reported stepwise wetland conversion, resulting in diverse land use types within the same wetland, ranging from unused or extensively grazed segments to field plots under both flood-tolerant and aerobic crops and eventually to the abandoning of degraded or pest-infested areas.

The analysis could show that wetland use systems are highly dynamic. Change can occur very rapidly and may not always follow the linearity implied by the conceptual transformation evolution depicted in 
Table 3 Amounts of N, P and K accumulated by 40 day-old rice shoots grown in a greenhouse under flooded and aerobic conditions in potted soil from different wetland types and land uses

\begin{tabular}{|c|c|c|c|c|c|c|}
\hline \multirow{2}{*}{$\begin{array}{l}\text { Land use (A) } \\
\text { Soil aeration }(B)^{\mathrm{a}}\end{array}$} & \multicolumn{2}{|c|}{$\mathrm{N}$ uptake $\left(\mathrm{mg} \operatorname{pot}^{-1}\right)$} & \multicolumn{2}{|c|}{$\mathrm{P}$ uptake $\left(\mathrm{mg} \mathrm{pot}^{-1}\right)$} & \multicolumn{2}{|c|}{$\mathrm{K}$ uptake $\left(\mathrm{mg} \mathrm{pot}^{-1}\right)$} \\
\hline & Flooded & Aerobic & Flooded & Aerobic & Flooded & Aerobic \\
\hline \multicolumn{7}{|l|}{ Lowland floodplain } \\
\hline Unused areas & $12.4 \mathrm{a}$ & $6.8 \mathrm{a}$ & $0.95 \mathrm{ab}$ & $0.42 \mathrm{~ns}$ & $3.27 \mathrm{~ns}$ & $2.91 \mathrm{~ns}$ \\
\hline Anaerobic cropping & $13.5 \mathrm{a}$ & $7.7 \mathrm{a}$ & $0.76 \mathrm{ab}$ & $0.31 \mathrm{~ns}$ & $2.22 \mathrm{~ns}$ & $2.99 \mathrm{~ns}$ \\
\hline Aerobic cropping & $9.4 \mathrm{ab}$ & $4.3 \mathrm{ab}$ & $1.49 \mathrm{a}$ & $0.42 \mathrm{~ns}$ & $3.12 \mathrm{~ns}$ & $3.73 \mathrm{~ns}$ \\
\hline Grazed fallow & $7.1 \mathrm{ab}$ & $3.0 \mathrm{ab}$ & $1.56 \mathrm{a}$ & $0.71 \mathrm{~ns}$ & $3.21 \mathrm{~ns}$ & $2.68 \mathrm{~ns}$ \\
\hline Abandoned & $3.0 \mathrm{~b}$ & $2.8 \mathrm{~b}$ & $0.57 b$ & $0.44 \mathrm{~ns}$ & $2.18 \mathrm{~ns}$ & $2.91 \mathrm{~ns}$ \\
\hline Soil aeration (B) & $* * *$ & & $* *$ & & ns & \\
\hline Interaction $(\mathrm{A} \times \mathrm{B})$ & ns & & $*$ & & ns & \\
\hline \multicolumn{7}{|l|}{ Highland floodplain } \\
\hline Unused areas & $29.2 \mathrm{ab}$ & $13.6 \mathrm{a}$ & $2.44 \mathrm{a}$ & $0.95 \mathrm{~ns}$ & $12.1 \mathrm{a}$ & $8.46 a$ \\
\hline Seasonal pasture & $13.8 \mathrm{~b}$ & $14.1 \mathrm{a}$ & $2.19 \mathrm{a}$ & $1.49 \mathrm{~ns}$ & $9.18 \mathrm{ab}$ & $8.65 a$ \\
\hline Aerobic cropping & $8.3 \mathrm{bc}$ & $9.1 \mathrm{ab}$ & $2.35 \mathrm{a}$ & $1.24 \mathrm{~ns}$ & $14.8 \mathrm{a}$ & $6.81 \mathrm{a}$ \\
\hline Abandoned & $4.3 \mathrm{c}$ & $5.3 b$ & $0.68 b$ & $0.58 \mathrm{~ns}$ & $8.47 \mathrm{ab}$ & $6.34 \mathrm{a}$ \\
\hline Soil aeration (B) & $*$ & & $* *$ & & ns & \\
\hline Interaction $(\mathrm{A} \times \mathrm{B})$ & ns & & $*$ & & ns & \\
\hline \multicolumn{7}{|l|}{ Highland valley } \\
\hline Unused areas & $19.9 \mathrm{a}$ & $11.2 \mathrm{a}$ & $1.93 \mathrm{~ns}$ & $1.38 \mathrm{ab}$ & $6.23 \mathrm{ab}$ & 7.34ab \\
\hline Seasonal pasture & $16.6 a b$ & $13.8 \mathrm{a}$ & $1.96 \mathrm{~ns}$ & $1.12 \mathrm{ab}$ & $12.94 \mathrm{a}$ & $7.50 \mathrm{ab}$ \\
\hline Anaerobic cropping & $19.3 \mathrm{a}$ & $10.0 \mathrm{a}$ & $2.64 \mathrm{~ns}$ & $2.33 \mathrm{a}$ & $14.72 \mathrm{a}$ & $8.35 \mathrm{a}$ \\
\hline Aerobic cropping & $6.8 \mathrm{~b}$ & $6.4 \mathrm{ab}$ & $2.14 \mathrm{~ns}$ & $1.98 \mathrm{~b}$ & $10.09 \mathrm{ab}$ & $5.76 \mathrm{bc}$ \\
\hline Abandoned & $4.1 \mathrm{~b}$ & $2.9 \mathrm{~b}$ & $1.05 \mathrm{~ns}$ & $1.68 \mathrm{~b}$ & $3.33 b$ & $2.97 \mathrm{c}$ \\
\hline Soil aeration (B) & $* *$ & & $\mathrm{~ns}$ & & $*$ & \\
\hline Interaction $(\mathrm{A} \times \mathrm{B})$ & $*$ & & ns & & ns & \\
\hline \multicolumn{7}{|l|}{ Mid-hill valley } \\
\hline Unused areas & $5.9 \mathrm{a}$ & $3.6 \mathrm{a}$ & $0.33 b$ & $0.34 \mathrm{ab}$ & $1.13 \mathrm{~b}$ & $2.18 \mathrm{~ns}$ \\
\hline Aerobic cropping & $3.8 \mathrm{ab}$ & $2.5 b$ & $0.64 \mathrm{a}$ & $0.55 \mathrm{a}$ & $4.59 \mathrm{a}$ & $2.16 \mathrm{~ns}$ \\
\hline Grazed fallow & $5.0 \mathrm{bc}$ & $1.7 b$ & $0.14 b$ & $0.16 b$ & $1.27 \mathrm{~b}$ & $1.08 \mathrm{~ns}$ \\
\hline Abandoned & $3.2 \mathrm{ab}$ & $1.8 \mathrm{~b}$ & $0.32 \mathrm{ab}$ & $0.16 b$ & $2.84 \mathrm{ab}$ & $1.14 \mathrm{~ns}$ \\
\hline Soil aeration (B) & $* * *$ & & $*$ & & ns & \\
\hline Interaction $(\mathrm{A} \times \mathrm{B})$ & ns & & $*$ & & ns & \\
\hline
\end{tabular}

Land uses are arranged according to their time sequence in the process of wetland conversion

$n s$ not significant at $P \leq 0.05$

$*, * *, * * *$ significant differences at $P \leq 0.05,0.01$ and 0.001 , respectively

a "Flooded" refers to of $1 \mathrm{~cm}$ of standing floodwater; "aerobic" refers to maintenance of field capacity by daily weighing, "Upland" refers to unused areas in the permanently aerobic wetland fringe or lower valley slope. Means in a column followed by the same letter(s) do not differ significantly by Tukey test $(P \leq 0.05)$

Fig. 2. In addition, various mixed forms of land use can occur. Namely grazing was not restricted to Stage 2, but could also be observed as "rotational" activity during the dry season with for example rainfed rice (Stage 3), or the grazing on temporarily "abandoned" plots (Stage 5) as also reported from other sites in East
Africa (Schuyt 2005). Also a direct conversion of a pristine wetland into a site of intense vegetable production after larger-scale drainage is now widely observed in peri-urban wetlands (IAASTD-International Assessment of Agricultural Knowledge, Science and Technology for Development 2009) and was 
Fig. 5 Regression relationships between biomass accumulation and the $\mathrm{N}, \mathrm{P}$ and $\mathrm{K}$ uptake by 40 day-old rice plants grown in potted soil. Data are plotted across wetland types and land uses. Nutrient uptake data were recalculated from mean biomass accumulation per pot and mean nutrient concentration in plant tissue $(n=3)$. Ll lowland (300-400 masl); Hl Highland (1,200-2,300 masl); $M H$ Mid-hills (800-1,000 masl)

also observed at the mid-hill sites in the present study. Such drastic changes in land use can be expected to accelerate with the development of infrastructure and marketing chains, and generally in environments with improved market accessibility and/or severe upland shortages as observed recently throughout the densely populated areas of the East African highlands (WMDMWE_-Wetlands Management Department, Ministry of Water and Environment, Uganda 2009). In all wetlands, truly abandoned plots were identified. The abandonment of these areas seemed to be associated with weed infestation (highland floodplain), soil-born pests and diseases (mid-hill valley) and soil fertility problems at all sites. The presence of such abandoned areas indicates that wetlands are not as resilient as usually portrayed but are rather vulnerable, particularly when agricultural uses involve large-scale drainage measures (Dixon and Wood 2003) or occur in the absence of input use or nutrient replenishment at the expense of the resource base quality (Henao and Baanante 2006). The resilience of such wetland systems may also depend on the degree of drainage (partial or seasonal), on soil resilience factors (mainly carbon content) (Sahrawat 2004) and on management strategies such as tillage operations or the return/ addition of organic amendments. The factors determining wetlands' resilience to anthropogenic interventions will require further studies, involving a larger number of wetlands in different environments.

Soil parameter changes

In the four wetland types, the soil parameters $\mathrm{C}, \mathrm{N}$, and available $\mathrm{P}$ responded differentially to land use. However, at all sites, abandoned lands tended to have the lowest concentrations and total amounts in these soil parameters. The gap in soil $\mathrm{C}$ and $\mathrm{N}$ contents between anaerobic and aerobic land use was wider in the soils of the lowland floodplain and the mid-hill valley than the highland wetlands. Higher temperatures at the sites of low altitude and the coarser soil texture may have contributed to the implied faster

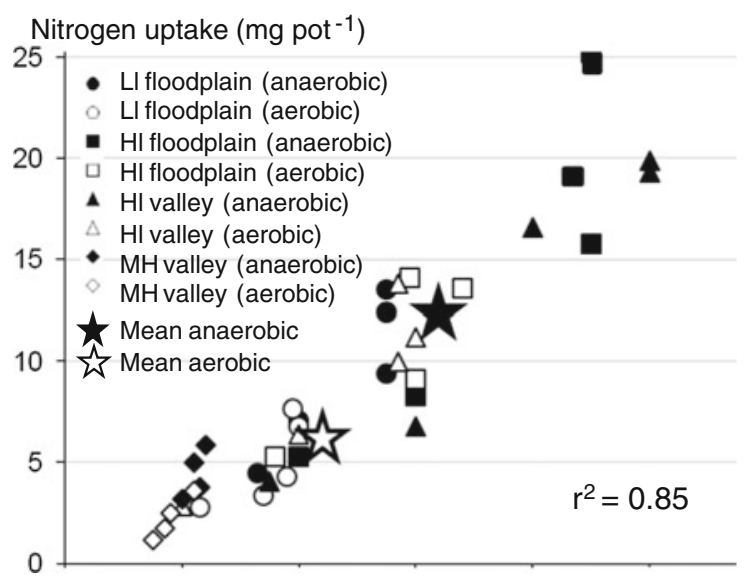

Phosphorus uptake $\left(\mathrm{mg} \mathrm{pot}^{-1}\right)$

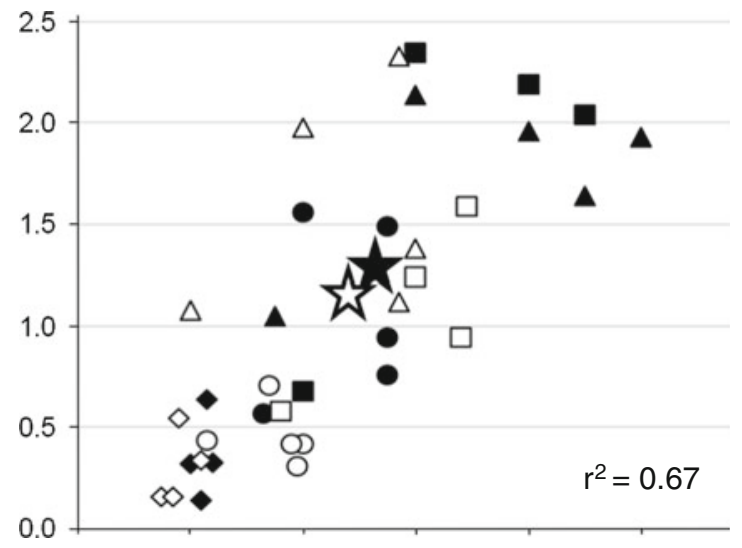

Potassium uptake $\left(\mathrm{mg} \mathrm{pot}^{-1}\right)$

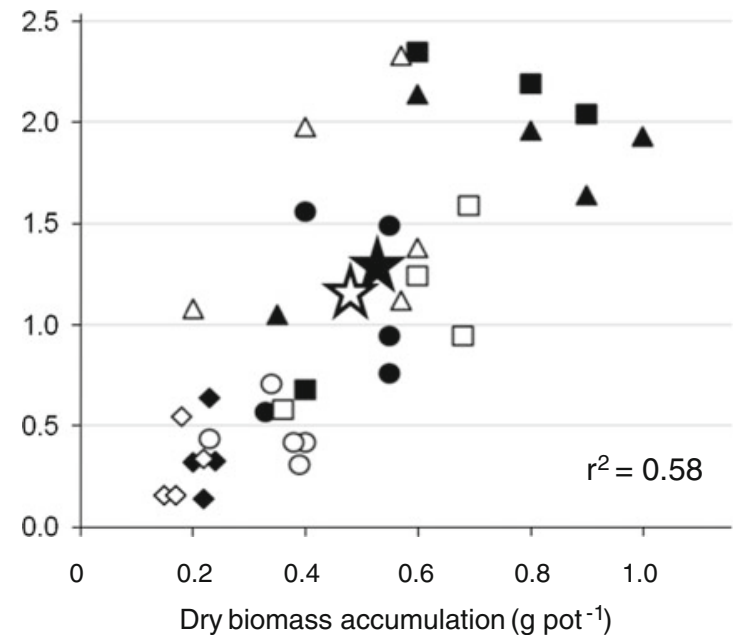

decomposition of soil organic matter at these sites. Soil texture may control organic $\mathrm{C}$ and $\mathrm{N}$ decomposition indirectly through its determination of soil water 
content and water filled pore space (Thomson et al. 1999). In all wetland types, soil $\mathrm{C}$ and $\mathrm{N}$ contents tended to decline from their "initial" land use stages of submergence and semi-natural vegetation or anaerobic cropping. Such conditions of predominant submergence and anaerobia allow for the accumulation of organic material and thus of soil organic $\mathrm{C}$ and $\mathrm{N}$ (Roth et al. 2011). When, on the contrary, the soil aeration status undergoes alternating aerobic and anaerobic cycles high impacts on soil organic matter and nutrients availability have been reported by (Regmi et al. 2002). Previous studies (Dawe et al. 2000), have reported declines in SOM from 12 to $9 \mathrm{~g} \mathrm{~kg}^{-1}$ from long-term trials under rice-wheat rotations in India, representing a similar system as the seasonally flooded wetlands in the present study. In the same study, soil organic matter in a rice monoculture maintained under aerobic conditions did not show such a decline. Even under low management intensity land uses, such as grazing, a change in soil aeration status can strongly affect soil $\mathrm{C}$ content (Pampolino et al. 2008). Thus, soil aeration status combined with tillage activities as well as the soil texture and initial soil organic $\mathrm{C}$ content are key determinants for fertility attribute changes in wetland soils.

With few exceptions, the available soil $\mathrm{P}$ contents were above the critical threshold levels (e.g. $5 \mathrm{mg} \mathrm{P} \mathrm{kg}{ }^{-1}$ ) at which for example a rice crop could be expected to respond positively to $\mathrm{P}$ fertilizer applications. However, at both highland wetland sites, the critical level for maize cultivation (15 $\mathrm{mg}$ available $\mathrm{P} \mathrm{kg}^{-1}$ ) was reached, and the difference in $\mathrm{P}$ contents between drained and abandoned and anaerobically cultivated land suggests soil P depletion by the crops. Also the low $\mathrm{P}$ content of the soil under rice production in the lowland floodplain suggests an emerging P deficit with continuous $\mathrm{P}$ removal and in the absence of any replenishment measure. Such trends have been observed in long-term continuously cultivated rice fields in Tanzania (Maitima et al. 2009) where P was diagnosed as the major limiting factor for crop production in the region. According to Dobermann et al. (1998), soil P contents do not always decrease with cultivation. The low available $P$ in some land use systems may simply be ascribed to a low inherent $P$ stock in the parent material (i.e. in the mid-hill inland valley or the lowland floodplain) or a low $\mathrm{P}$ availability under the prevailing soil conditions ( $\mathrm{pH}$, Eh, element concentrations). An apparent accumulation of $\mathrm{P}$ was observed for land under aerobic cultivation in the mid-hill valley where $\mathrm{P}$ contents were significantly higher than under all other land use types. Very likely, this can be explained by regular fertilizer inputs of $10-15 \mathrm{~kg} \mathrm{P} \mathrm{ha}^{-1}$ to vegetables that were produced for the Dar-es-Salaam market.

Effect of soil aeration status and land use on crop response

We tested the production potential of the wetland soils in a pot experiment where rice grew for 40 days on the very small soil volume of about $300 \mathrm{~cm}^{3}$. We assume that this led to an exhaustion of the soils' delivery capacity for major nutrients. Thus we treated the biomass production on soils of various land use types as a proxy for the relative production potential of these soils.

The production potential of soils of any previous land use was generally higher when the soils were submerged during the test period. Flooding a soil sets in motion chemical and electrochemical processes that affect the supply of nutrients and their uptake by a crop. In flooded soil, ammonia $\left(\mathrm{NH}_{4}{ }^{+}\right)$is the dominant $\mathrm{N}$ form while in aerobic soils nitrate $\left(\mathrm{NO}_{3}{ }^{-}\right)$dominates over $\mathrm{NH}_{4}{ }^{+}$. With alternating drying and wetting (which may be a characteristic of frequently irrigated aerobic soils), nitrification/denitrification processes are stimulated and may lead to a rapid loss in soil $\mathrm{N}$ (Becker et al. 2007). However, flooding affects more than the $\mathrm{N}$ form as it improves the movement of nutrients by mass flow or diffusion. The reduced conditions favor the plant availability of $\mathrm{Fe}, \mathrm{Mn}$, and $\mathrm{Cu}$ through reductive processes. On the other hand, the availability of $\mathrm{Zn}$ may be reduced in submerged soils, particularly when organic C content is high (Xiaopeng et al. 2012). On the other hand, high root densities, which can be expected in pot experiments with low soil volumes, may help to overcome limitations in $\mathrm{Zn}$ through accumulated excretion of phytosiderophores (Ptashnyk et al. 2011).

Rice biomass production correlated well with plant nutrient uptake, particularly that of N. For all wetland soils, an increase in biomass production coincided with an increase in plant tissue $\mathrm{N}$ concentrations, whereby significantly higher $\mathrm{N}$ uptake was observed from flooded compared to aerobic soils. This combined with the relatively high $\mathrm{r}^{2}$ values for $\mathrm{N}$ suggest that currently $\mathrm{N}$ is still the most limiting nutrient element for crop production in all wetlands and land use types, whereby soil drainage/drying further enhanced $\mathrm{N}$ limitations. No such trends were apparent 
for $\mathrm{P}$ and $\mathrm{K}$. The tissue $\mathrm{K}$ concentrations were generally $<0.9 \%$, indicating that $\mathrm{K}$ may become a limiting element in the future. Plant tissue concentrations of $\mathrm{P}$ had a weak relationship with biomass accumulation. In contrast to $\mathrm{N}$, soil aeration status has generally little effect on $\mathrm{P}$ availability. Differences in $\mathrm{P}$ uptake appear to be more related to the wetland type (low in the coarse-textured lowland floodplain and mid-hill valley soils, high in the fine-textured highland valley and floodplain soils) and the prevailing production system/fertilizer P application rate. However, in general, contents of available soil nutrients differed between land use types and increased from abandoned plots to areas under natural vegetation.

\section{Conclusions}

The general assumption that wetlands can be considered resilient to anthropogenic interventions is not necessarily true as aerobic land uses strongly affected soil parameters (especially soil $\mathrm{C}$ and $\mathrm{N}$ ) and production potential. Also, a pristine wetland is not necessarily per se rich in stock and content/concentration of carbon and essential plant nutrients. The declines in soil $\mathrm{C}$ and $\mathrm{N}$ contents upon land use intensification are in themselves not surprising. However, especially the differences in the extent of these declines highlight that different wetland situations (wetland type, soil, land and water management) are differentially affected. Thus, some wetlands are apparently more resilient towards agricultural use, highlighting the possibility of a sustainable intensification, while other wetlands are more vulnerable. The low available soil $\mathrm{P}$ values and the presence of abandoned land indeed indicate that active management is necessary to maintain the production potential/soil fertility of the studied wetlands. Early management intervention may be called for on soils of coarse texture when they are heavily cropped, especially in drained/aerobic systems. Nevertheless, the tendency to improved production potential when soils of almost all wetland and land use types were submerged implies the perspective that initial production potential can be partly restored.

Acknowledgments This study was conducted within the framework of the project "Agricultural Use and Vulnerability of Small Wetlands of East Africa" supported by the Volkswagen Foundation, Hannover Germany. We also acknowledge the support of laboratory staff at the Kenya
Agricultural Research Institute and Kenya, Department of Soil Surveys, Nairobi, Kenya.

\section{References}

Alvarez M, Becker M, Böhme B, Handa C, Josko M, Kamiri HW, Langensiepen M, Menz G, Misana S, Mogha NG, Möseler BM, Mwita EJ, Oyieke HA, Sakané N (2012) Floristic classification of the vegetation in small wetlands of Kenya and Tanzania. Biodivers Ecol 4:63-76

Anderies JM, Janssen MA, Ostrom E (2004) A framework to analyse the robustness of social-ecological systems from an institutional perspective. Ecol Soc 9:18

Balasubramanian V, Sie M, Hijmans RJ, Otsuka K (2007) Increasing rice production in sub-saharan Africa: challenges and opportunities. Adv Agron 94:55-133

Becker M, Johnson DE (2001) Cropping intensity effects on upland rice yield and sustainability in West Africa. Nut Cyc Agroecosys 59:107-117

Becker M, Ladha JK, Simpson IC, Ottow JCG (1994) Parameters affecting residue nitrogen release in flooded soil. Soil Sci Soc Am J 58:1666-1671

Becker M, Asch F, Maskey S, Pande K, Shah S, Shrestha S (2007) Effects of transition season management on soil N dynamics and system $\mathrm{N}$ balances in rice-wheat rotations of Nepal. Field Crop Res 103:98-108

Bernal B, Mitsch WJ (2008) A comparison of soil carbon pools and profiles in wetlands in Costa Rica and Ohio. Ecol Eng 34:311-323

Bewket W, Stroosnijder L (2003) Effects of agroecological land use succession on soil properties in Chemoga watershed, Blue Nile basin, Ethiopia. Geoderma 111:85-98

Brady NC, Weil RR (2008) The nature and properties of soils. Pearson Prentice Hall, Upper Saddle River

Daily GC, Polasky S, Goldstein J, Kareiva PM, Mooney HA, Pejchar L, Ricketts TH, Salzman J, Shallenberger R (2009) Ecosystem services in decision making: time to deliver. Front Ecol Environ 7:21-28

Dawe D, Dobermann A, Moya P, Abdulrachman S, Singh B, Lal P, Li SY, Lin B, Panaullah G, Sariam O, Singh Y, Swarup A, Tan PS, Zhen Q (2000) How widespread are yield declines in long-term rice experiments in Asia? Field Crop Res 66:175-193

Dixon AB, Wood AP (2003) Wetland cultivation and hydrological management in East Africa: matching community and hydrological needs through sustainable wetland use. Nat Resour Forum 27:117-129

Dobermann A, Cassman KG, Mamaril CP, Sheehy JE (1998) Management of phosphorus, potassium and sulfur in intensive, irrigated lowland rice. Field Crop Res 56:113-138

Hartemink AE (2006) Assessing soil fertility decline in the tropics using soil chemical data. Adv Agron 89:179-225

Henao J, Baanante C (2006) Agricultural production and nutrient mining in Africa: implications for resource conservation and policy. IFDC, Muscle Shoals

IAASTD-International Assessment of Agricultural Knowledge, Science and Technology for Development (2009) In: McIntyre BD et al (eds) Agriculture at a crossroad—global report. Island Press, Washington DC, USA 
Jeroen CJ, van den Bergh M, Barendregt A (2004) Spatial ecological-economic analysis for wetland management: modeling and scenario evaluation of land use. Cambridge University Press, Cambridge

Kirk G (2004) The biogeochemistry of submerged soils. Wiley, Chichester

Ladha JK, Dawe D, Pathak H, Padre AT, Yadav RL, Singh B, Singh Y, Singh P, Kundu AL, Sakal R, Ram N, Regmi AP, Gami SK, Bhandari AL, Amin R, Yadav CR, Bhattarai EM, Das S, Aggarwal HP, Gupta RK, Hobbs PR (2003) How extensive are yield declines in long-term rice-wheat experiments in Asia? Field Crop Res 81:159-180

Maitima J, Mugatha SM, Reid RS, Gachimbi LN, Majule A, Lyaruu H, Pomeroy D, Mathai S, Mugisha S (2009) The linkages between land-use change, land degradation and biodiversity across East Africa. Afr J Environ Sci Technol $3: 310-325$

Millennium Ecosystem Assessment (MEA) (2005) Ecosystems and human well-being: wetlands and water synthesis. World Resources Institute, Washington D.C

Mitsch WJ, Gosselink JG (2007) Wetlands. Wiley, Hoboken

Mwita EJ, Menz G, Misana S, Becker M, Kisnaga D, Boehme B (2012) Mapping small wetlands of Kenya and Tanzania using remote sensing techniques. Int J Appl Earth 21: 173-183

Ndakidemi PA, Semoka JMR (2006) Soil fertility survey in Western Usambara Mountains, Northern Tanzania. Pedosphere 16:237-244

Oucho JO, Gould WTS (1993) Internal migration, urbanization and population distribution. In: Foote KA, Hill KH, Martin LG (eds) Demographic change in Sub-Saharan Africa. National Academic Press, Washington D.C

Pampolino MF, Laureles EV, Gines HC, Buresh RJ (2008) Soil carbon and nitrogen changes in long-term continuous lowland rice cropping. Soil Sci Soc Am J 72:798-807

Ptashnyk M, Roose T, Jones DJ, Kirk GD (2011) Enhanced zinc uptake by rice through phytosederophore secretion: a modeling study. Plant Cell and Environ 34:2038-2046

Rebelo LM, McCartney MP, Finlayson CM (2010) Wetlands of sub-Saharan Africa: distribution and contribution of agriculture to livelihoods. J Wetlands Ecol Manage 18:557-572

Regmi AP, Ladha JK, Pathak H, Pasuquin E, Bueno C, Dawe D, Hobbs PR, Joshy D, Maskey SL, Pandey SP (2002) Yield and soil fertility trends in a 20-year rice-rice-wheat experiment in Nepal. Soil Sci Soc Am J 66:857-867

Roth PJ, Lehndorff E, Cao Z, Zhuang S, Bannert A, Wissing L, Schloter M, Kögel-Knabner I, Amelung W (2011) Accumulation of nitrogen and microbial residues during 2000 years of rice paddy- and non-paddy soil development in the
Yangtse River Delta, China. Glob Change Biol 17: 3405-3417

Sahrawat KL (2004) Organic matter accumulation in submerged soils. Adv Agron 81:169-201

Sakane N, Alvarez M, Becker M, Böhme B, Handa C, Kamiri HW, Langensiepen M, Menz G, Misana S, Mogha N, Möseler B, Mwita E, Oyieke AH, van Wijk M (2011) Classification, characterization, and use of small wetlands in East Africa. Wetlands 31:1103-1116

Sakane N, Becker M, Langensiepen M, van Wijk MT (2012) Typology of smallholder production systems in small East African wetlands. Wetlands. doi:11.1007/s13157-0120221-4

Schuyt KD (2005) Economic consequences of wetland degradation for local populations in Africa. Ecol Econ 53: 177-190

Silvius MJ, Oneka M, Verhagen A (2000) Wetlands: lifeline for people at the edge. Phys Chem Earth Pt B 25:645-652

Stevenson N, Frazier S (1999) Review of wetland inventory information in Africa. In: Finlayson CM, Spiers AG (eds) Global review of wetland resources and priorities for wetland inventory. Supervising scientist report 144. Wetlands International Publications 53, Supervising scientist, Canberrra, Australia

Thenya T (2001) Challenges of conservation of dryland shallow waters, Ewaso Narok swamp, Laikipia District, Kenya. Hydrobiologia 458:107-119

Thomson IK, Schjønning P, Jensen B, Kristensen K, Christensen BT (1999) Turnover of organic matter in differentially textured soils II. Microbila activity as influenced by soil water regimes. Geoderma 89:199-218

van der Heyden CJ, New MG (2003) The role of a dambo in the hydrology of a catchment and the river network downstream. Hydrol Earth Sys Sci 7:339-357

Verhoeven JT, Setter TL (2010) Agricultural use of wetlands: opportunities and limitations. Ann Bot Lond 105:155-164

WMD-MWE-Wetlands Management Department, Ministry of Water and Environment, Uganda (2009) Mapping a better future: how spatial analysis can benefit wetlands and reduce poverty in Uganda. World Resources Institute, Washington D.C

Wood A, van Halsema GE (2008) Scoping agriculture-wetland interactions: towards a sustainable multiple-response strategy. FAO Water Report 33. Food and Agriculture Organization of the United Nations, Rome

Xiaopeng G, Hoffland E, Stomph TJ, Grant CA, Zou C, Zhang F (2012) Improving zinc bioavailability in transition from flooded to aerobic rice. A rev Agron Sustain Dev 32: $465-478$ 